\title{
SUBCONTRACTOR SELECTION USING THE INTEGRATION OF THE AHP AND PROMETHEE METHODS
}

\author{
Gul POLAT \\ Department of Civil Engineering, Istanbul Technical University, Insaat Fakultesi, \\ Maslak, 34469, Istanbul, Turkey
}

Received 19 Nov 2013; accepted 23 May 2014

\begin{abstract}
On many construction projects, especially building projects, $80-90 \%$ of the tasks are performed by subcontractors. Since the success of the project highly depends on the performances of the subcontractors, selecting the right subcontractor for the right job is critical. Main contractors generally tend to select the subcontractors that offer the lowest bid price. However, working with unqualified and insufficiently financed subcontractors may result in inefficiencies and failures. Thus, a combination of several compromising and conflicting criteria underpinning financial capacity and competencies of the subcontractors should be considered during the subcontractor selection process. This paper proposes an integrated decision approach, which employs analytic hierarchy process (AHP) and preference ranking organization method for enrichment evaluations (PROMETHEE) together, for the subcontractor selection problem. In the proposed approach, AHP is used to analyze the structure of the subcontractor selection problem and to determine the weights of the criteria, and PROMETHEE is employed to obtain complete ranking and perform sensitivity analysis by changing the weights of criteria. The proposed approach is applied to a problem of selecting the most appropriate subcontractor to be worked with in an international construction project. Company management found the proposed decision approach satisfactory and implementable in future subcontractor selection problems.
\end{abstract}

Keywords: subcontractor selection, multi-criteria-decision-making, AHP, PROMETHEE, GAIA, sensitivity analysis.

\section{Introduction}

A subcontractor is a construction company that contracts with a main contractor to undertake specific tasks on a project as part of the overall contract and may supply laborers, materials, equipment, tools, and designs (Arditi, Chotibhongs 2005; Eom et al. 2008). Subcontractors can be classified according to the services and/or resources they supply. Mbachu (2008) categorized subcontractors into three types, which are: 1) trade contractors that specialize on specific trades such as paintwork, brickwork, etc.; 2) specialist subcontractors that carry out specialist services such as electrical, plumbing, insulation, etc.; and 3) the labor-only-subcontractors that provide laboronly services such as skilled craftsmen. $\mathrm{Ng}$ et al. (2009) classified subcontractors into two main types, which are: 1) equipment-intensive subcontractors that are predominantly hired as a result of their specialized plant and equipment; and 2) labor-intensive subcontractors that are mainly hired on the basis of their specialized labor resources. Nowadays, in most construction projects, main contractors only act as construction management agents (Cooke, Williams 1998; Arslan et al. 2008) and are more involved in site organization and management tasks (Humphreys et al. 2003), and subcontract large portions or all of the specialized work on their projects to subcontractors. In other words, subcontractors carry out the actual production work whereas main contractors only control whether the work is performed according to the conditions specified in the main contract and related specifications (Ulubeyli et al. 2010). On many construction projects, especially building projects, 80 $90 \%$ of the tasks are performed by subcontractors (Hinze, Tracey 1994).

In past decades, subcontracting was not practiced as widely as it is today. There are several reasons why main contractors rely heavily on the services of subcontractors. First, the complexity of the construction projects has considerably increased. Thus, it is not possible for an average main contractor to complete such complex projects by himself. Second, the average main contractor is not able to afford full-time employment of skilled craftsmen in each of the several specialized trades needed to complete the construction projects. Third, it is not feasible for main contractors to own, operate, control, and maintain specialized plants and equipment that may have only limited use throughout the project. Fourth, subcontractors are able to carry out their specialized tasks more quickly at a lower cost with higher quality than the main

Corresponding author: Gul Polat

E-mail:polatgu@itu.edu.tr,gulpola@gmail.com 
contractor because of their unique skills (Hsieh 1998; Arditi, Chotibhongs 2005; Choudhry et al. 2012). Another reason for subcontracting is that the main contractor may ease cash flow problems and the challenge of financing the project by subcontracting a large portion of the work. Furthermore, the main contractor shares his risks on the project with the subcontractors, which enables main contractors to survive volatile and uncertain conditions of the construction industry (Mbachu 2008; Choudhry et al. 2012). Although subcontracting offers several benefits to main contractors, it is a rather risky practice. In general, the main contractor enters into contractual arrangements with the subcontractors, and is fully responsible to the owner for the performance of the subcontractors in terms of time, cost, and quality. In construction projects where a large portion of the works is subcontracted out, if the main contractor does not have sufficient construction management skills, he may likely fail to coordinate and control the quality and progress of the works of the subcontractors, which in turn may bring about project defaults (Cooke, Williams 1998; Okoroh, Torrance 1999; Kumaraswamy, Matthews 2000; Cox et al. 2006; Karim et al. 2006; $\mathrm{Ng}$ et al. 2009). In this context, the success of the main contractor in a construction project highly depends on the performances of the subcontractors involved in the project in question ( $\mathrm{Ng}$ et al. 2009). Therefore, selecting the right subcontractors is crucial not only to successful project delivery but also the performance, reputation, and survival of the main contractors (e.g. Shash 1998; Arslan et al. 2008; Mbachu 2008; Hartmann et al. 2009; Hartmann, Caerteling 2010).

Despite of the fact that selecting appropriate subcontractors is pivotal to overall project performance, main contractors generally do not have adequate time to search for all potential subcontractors to be worked with, communicate with them, and evaluate them systematically (Tserng, Lin 2002; Ulubeyli et al. 2010) as subcontractors are commonly selected after the main contractor signs the contract with the owner and only when subcontractors' portion of the work is near. Therefore, main contractors either tend to select the subcontractors based on the lowest bid price (Tserng, Lin 2002; Luu, Sher 2006; Arslan et al. 2008; Mbachu 2008; Hartmann et al. 2009) or prefer to work with familiar subcontractors that had already done business with them in previous projects (Tserng, Lin 2002; Arslan et al. 2008; Ulubeyli et al. 2010; Choudhry et al. 2012). Considering the lowest price as the only award criterion may cause main contractors to select unqualified, incompetent, inexperienced, and insufficiently financed subcontractors, and thereby lose a huge amount of money in the long run. Indeed, selecting inappropriate subcontractors could induce immense additional costs such as reworks due to poor quality of work, claims, disputes, litigations, adversarial working conditions, penalties, abandonment of work, bankruptcy, etc. Therefore, main contractors should consider not only the bid price but also several compromis- ing and conflicting criteria underpinning financial capacity and competencies of the subcontractors (Arslan et al. 2008; Mbachu 2008; Ulubeyli et al. 2010). Selecting the known subcontractors offers several benefits to main contractors such as flexibility, stability, mutual trust, and decrease of transaction and search costs. In spite of these benefits, working with known subcontractors may bring about some problems such as the managerial bottlenecks resulted from personal relationships, difficulties in cost control and adoption of new technological skills and innovations, inefficiencies in subcontractor selection and negotiation processes due to limitations on finance, manpower, time, and information (Tserng, Lin 2002).

The main objective of this study is to propose an integrated decision approach, which employs AHP and PROMETHEE together, for the selection of the most appropriate subcontractor among a set of available alternatives considering several compromising and conflicting criteria. In the proposed approach, AHP is used to analyze the structure of the subcontractor selection problem and to determine the weights of the criteria, and the PROMETHEE method is employed to obtain complete ranking and perform sensitivity analysis by changing the weights of criteria. In order to illustrate how the proposed approach can be used in a real situation, it was applied to a problem of selecting the most appropriate subcontractor to be worked with in an international construction project.

The integration of AHP and PROMETHEE methods have been successfully implemented in various fields such as information systems outsourcing (Wang, Yang 2007), equipment selection (Dagdeviren 2008), policy scenario selection (Turcksin et al. 2011), supply chain risk prioritization (Venkatesan, Kumanan 2012), and mining method selection (Bogdanovic et al. 2012).

\section{Previous studies in contractor/subcontractor selection methods}

In the construction management literature, a great number of studies have dealt with the problem of evaluating/ selecting contractor. These studies have different focuses. While some of them attempted to identify the most commonly used assessment criteria for bid evaluation (e.g. Wong et al. 2000; Singh, Tiong 2006; Waara, Bröchner 2006; Bendaña et al. 2008), the remainders proposed various contractor evaluation/selection methodologies, tools, and methods. In this section, some of these studies are briefly mentioned. Holt et al. (1994) provided example applications of multi-attribute analysis for selecting contractors. Hatush and Skitmore (1998) used multi-criteria utility theory for evaluating construction bidders. Elazouni and Metwally (2000) employed linear programming as a decision support system for subcontracting construction works. Palaneeswaran and Kumaraswamy (2000) developed a model for contractor prequalification and bid evaluation in design and build projects. Fong and Choi (2000) proposed an approach employing the analytical 
hierarchy process for final contractor selection. Alarcón and Mourgues (2002) developed a system for evaluating and selecting contractor. In this system, the contractor's performance is predicted and used as one of the criteria for selection. Sönmez et al. (2002) applied evidential reasoning to prequalifying and selecting construction contractors. Mahdi et al. (2002) proposed the use of multicriteria approach in contractor selection. Cheng and $\mathrm{Li}$ (2004) developed a model using the analytic network process for contractor selection. Topcu (2004) proposed a decision model for construction contractor selection in Turkey. Singh and Tiong (2005) developed a fuzzy decision framework for contractor selection. Zavadskas et al. (2005) applied game theory to selecting dwelling maintenance contractors. Zavadskas and Vilutiene (2006) presented a model based on the multiple criteria analysis for selecting dwelling maintenance contractors. Zavadskas et al. (2008) presented a contractors' assessment and selection model based on the multi-attribute methods in a competitive and risky environment. Brauers et al. (2008) applied the MOORA method, which is based on ratio analysis and dimensionless measurement, to rank the contractors objectively. They approached the largest maintenance contractors of dwellings in Vilnius as an application. Bendaña et al. (2008) employed fuzzycontrol approach and built artificial neural network for selecting contractors. Juan et al. (2009) proposed a hybrid approach that combines fuzzy set theory and quality function deployment (QFD) to select housing refurbishment contractor. Zavadskas et al. (2009a) demonstrated the concept of general contractor choice on the basis of multiple attributes of efficiency with fuzzy inputs applying COPRAS-G method through a case study. Zavadskas et al. (2009b) presented the comparative analysis of dwelling maintenance contractors aimed at determining the degree of their utility for users and bidding price of services by applying the method of multi-criteria complex proportional assessment. Darvish et al. (2009) applied the graph theory and matrix methods to selecting contractor. Bendaña-Jácome et al. (2010) applied neural networks to extract knowledge for contractor selection in traditional design-bid-build projects. Zavadskas et al. (2010) proposed the use of SAW-G and TOPSIS Grey Techniques in contractor selection. Arslan (2012) developed a web-based contractor evaluation system (WEBCONTEST) by which the contractors can be evaluated based on a combined criterion.

In addition to the studies dealing with the problem of evaluating/selecting contractor, few studies focused on subcontractor selection. Albino and Garavelli (1998) discussed an application of neural networks to support general contractor management in subcontractor rating. Okoroh and Torrance (1999) proposed a fuzzy model for the selection of subcontractors in refurbishment projects. Kumaraswamy and Mathews (2000) showed how partnering principles can be applied to the subcontractor selection process. Tserng and Lin (2002) developed an integrated XML (eXtensible Markup Language) of Accelerated Subcontracting and Procuring (ASAP) model using the combination of the quick mechanism of information technology with portfolio theory in financial management. Ip et al. (2004) developed a branch and bound algorithm for subcontractor selection and applied this approach to an experimental example drawn from an actual construction project of coal-fire power station. Luu and Sher (2006) developed a case-based reasoning procurement advisory system for subcontractor selection. Ko et al. (2007) developed Subcontractor Performance Evaluation Model (SPEM) using an Evolutionary Fuzzy Neural Inference Model (EFNIS) as a learning and inference engine to perform the assessment process. Arslan et al. (2008) developed a web-based subcontractor evaluation system (WEBSES) that enables main contractors to evaluate the subcontractors based on a combined criterion. Abbasianjahromi et al. (2013) developed a comprehensive model for subcontractor selection based on the fuzzy preference selection index.

This study aims to make the subcontractor selection process more objective, less complex, less time consuming, and more user friendly by proposing a decision approach. For this purpose, an integrated decision approach, which employs AHP and PROMETHEE together, is developed to help construction companies, namely main contractors, for the selection of the most appropriate subcontractor among a set of available alternatives. The proposed approach is applied to a problem of selecting the most appropriate subcontractor to be worked with in an international construction project.

\section{Subcontractor selection process}

It is commonly acknowledged that there is a need for objective decision-making through reliable subcontractor evaluation criteria and methodologies in subcontractor selection practice (e.g. Tserng, Lin 2002; Arslan et al. 2008; Eom et al. 2008; Ulubeyli et al. 2010). However, formulizing the problem of subcontractor evaluation is very complicated as it is affected by the combination of several quantitative and qualitative factors (Albino, Garavelli 1998; Luu, Sher 2006) and there is no consensus about the factors that should be taken into account during the subcontractor evaluation process. In the literature, various subcontractor selection criteria have been proposed by several researchers. The most frequently cited subcontractor selection criteria are presented in Table 1.

As seen in Table 1, a great number of criteria have been proposed for subcontractor selection and this list can easily be extended. However, when the number of criteria increases, the subcontractor selection becomes more complex as qualifying candidate subcontractors based on each criterion becomes very difficult. Moreover, it is not an easy task for main contractors to evaluate in advance the quality of resources, capacities and capabilities of the subcontractors, especially unknown subcontractors (Ngowi, Pienaar 2005). Therefore, the number 
Table 1 . The most frequently cited subcontractor selection criteria

\begin{tabular}{|c|c|}
\hline Subcontractor selection criteria & Sources \\
\hline Bid price & $\begin{array}{l}\text { Cooke and Williams (1998), Okoroh and Torrance (1999), Mbachu (2008), Eom et al. } \\
\text { (2008), Arslan et al. (2008), Hartmann et al. (2009), Hartmann and Caerteling (2010), } \\
\text { Choudhry et al. (2012) }\end{array}$ \\
\hline Financial status & Cooke and Williams (1998), Okoroh and Torrance (1999), Arslan et al. (2008) \\
\hline $\begin{array}{l}\text { Adequacy of resources (workers, } \\
\text { equipment, materials, etc.) }\end{array}$ & Cooke and Williams (1998), Mbachu (2008), Arslan et al. (2008), Choudhry et al. (2012) \\
\hline Experience in similar works & $\begin{array}{l}\text { Cooke and Williams (1998), Okoroh and Torrance (1999), Mbachu (2008), } \\
\text { Arslan et al. (2008) }\end{array}$ \\
\hline Current commitment/workload & Cooke and Williams (1998) \\
\hline Quality performance & $\begin{array}{l}\text { Cooke and Williams (1998), Okoroh and Torrance (1999), Eom et al. (2008), Arslan et al. } \\
\text { (2008), Hartmann et al. (2009), Hartmann and Caerteling (2010), Choudhry et al. (2012) }\end{array}$ \\
\hline Safety performance & Okoroh and Torrance (1999), Eom et al. (2008), Arslan et al. (2008) \\
\hline $\begin{array}{l}\text { Experience in the construction } \\
\text { industry }\end{array}$ & Okoroh and Torrance (1999), Arslan et al. (2008) \\
\hline Ability to complete work on time & $\begin{array}{l}\text { Okoroh and Torrance (1999), Mbachu (2008), Eom et al. (2008), Arslan et al. (2008), } \\
\text { Choudhry et al. (2012) }\end{array}$ \\
\hline Technical competence & $\begin{array}{l}\text { Cooke and Williams (1998), Okoroh and Torrance (1999), Eom et al. (2008); } \\
\text { Hartmann et al. (2009), Hartmann and Caerteling (2010) }\end{array}$ \\
\hline $\begin{array}{l}\text { Relationship with the main } \\
\text { contractor }\end{array}$ & $\begin{array}{l}\text { Cooke and Williams (1998), Okoroh and Torrance (1999), Mbachu (2008), } \\
\text { Hartmann et al. (2009), Hartmann and Caerteling (2010), Choudhry et al. (2012) }\end{array}$ \\
\hline $\begin{array}{l}\text { Reputation/compliance with } \\
\text { company image }\end{array}$ & Cooke and Williams (1998), Okoroh and Torrance (1999), Arslan et al. (2008) \\
\hline Accessibility to the subcontractor & Okoroh and Torrance (1999), Arslan et al. (2008) \\
\hline
\end{tabular}

of the criteria used in the subcontractor selection process should be low enough to assure that the decision-makers can easily evaluate all potential subcontractors based on these criteria and high enough to guarantee that all of the principal criteria are incorporated into the decision mechanism.

\section{Principles of AHP and PROMETHEE methods}

In this section, the principles of AHP and PROMETHEE methodologies will be briefly described.

\subsection{The AHP method}

AHP, first developed by Saaty (1980), is one of the most commonly used techniques for solving complex multicriteria-decision-making (MCDM) problems. The main idea behind AHP is to divide complicated and unstructured multi-criteria-decision problems into manageable and measurable components. AHP comprises six main steps, which are (Saaty 1980):

1. Define the decision problem and determine its goal.

2. Establish the decision hierarchy in which the highest level denotes the goal of the decision problem, the middle level represents multiple criteria, and the lowest level indicates the alternatives. This hierarchy indicates a relationship between the elements of a level with those of the level immediately below.

3. Compare the elements in the corresponding level in pairs according to their levels of influence on the specified element in the higher level of the decision hierarchy. In AHP, multiple pairwise comparisons are made based on a standardized nine-point scale of measurement. This scale of nine levels converts the human preferences between available alternatives as equal importance, weak importance, strong importance, very strong importance, and absolute importance.

Let $C=\left\{C_{j} \mid j=1,2, \ldots, n\right\}$ be the set of criteria. The result of the pairwise comparison on $\mathrm{n}$ criteria can be summarized in an $(n \times n)$ evaluation matrix $A$ in which every element $a_{i j}(i, j=1,2, \ldots, n)$ is the quotient of weights of the criteria, as shown in Eqn (1):

$$
A=\left[\begin{array}{ccc}
a_{11} & \cdots & a_{1 n} \\
\vdots & \ddots & \vdots \\
a_{n 1} & \cdots & a_{n n}
\end{array}\right],
$$

where: $a_{i i}=1, a_{j i}=1 / a_{i j}, a_{i j} \neq 0$.

This requires $n \times(n-1) / 2$ pairwise comparisons.

4. Synthesize all of the pairwise comparison matrices to find the relative priority for each criterion/alternative. This process includes two main steps: First, each element of a pairwise comparison matrix is divided by its column total to establish normalized pairwise comparison matrix. Then, the average of the elements in each row of the normalized pairwise comparison matrix is calculated to develop priority vector.

5. Determine the consistency ratio $(C R)$ of the pairwise comparisons. The steps in determining the consistency ratio are as follows: First, the weighted sum matrices are established through multiplying pairwise comparison matrices by priority vectors. Second, the eigenvalues are computed by dividing all the elements of 
the weighted sum matrices by their respective priority vector element. Third, the principal eigenvector $\left(\lambda_{\max }\right)$ is calculated by taking the average of the eigenvalues. Fourth, the consistency index (CI) is computed using Eqn (2):

$$
C I=\left(\lambda_{\max }-n\right) /(n-1),
$$

where: $\lambda_{\max }$ is the principal eigenvalue and $n$ is the matrix size.

6. Finally, $C R$ is calculated using Eqn (3):

$$
C R=C I / R I,
$$

where: $R I$ is the random index.

The $C R$ is acceptable; if it is lower than 0.10. Otherwise, the judgment matrix is considered to be inconsistent and the pairwise comparisons should be reviewed and improved in order to obtain a consistent matrix.

\subsection{The PROMETHEE method}

The PROMETHEE method is one of the most commonly used multi-criteria-decision-making methods. It is a quite simple outranking method for a set of alternatives to be ranked and selected among multiple conflicting criteria. The PROMETHEE family of outranking methods, including the PROMETHEE I for partial ranking of the alternatives and the PROMETHEE II for complete ranking of the alternatives, were first developed by Brans in 1982 (Brans, Mareschal 2005). Several versions of the PROMETHEE methods such as PROMETHEE III for ranking based on interval, the PROMETHEE IV for complete or partial ranking of the alternatives when the set of viable solutions is continuous, the PROMETHEE V for problems with segmentation constraints, the PROMETHEE VI for the human brain representation, the PROMETHEE GDSS for group decision-making, the visual interactive module GAIA (Geometrical Analysis for Interactive Aid) for graphical representation, the PROMETHEE TRI for dealing with sorting problems, and the PROMETHEE CLUSTER for nominal classification were developed to solve complicated decision-making situations (Macharis et al. 1998; Brans, Mareschal 2005; Behzadian et al. 2010). In this study, three PROMETHEE tools will be used to analyze the subcontractor selection problem, which include: 1) the PROMETHEE I partial ranking; 2) the PROMETHEE II complete ranking; and 3) the Geometrical Analysis for Interactive Aid (GAIA).

PROMETHEE comprises eight main steps, which are (Brans, Mareschal 2005; Dagdeviren 2008; Behzadian et al. 2010):

1. Determine the criteria $(j=1, \ldots, k)$ and the set of possible alternatives (A) of a decision problem.

2. Determine the weights of the criteria. These weights are non-negative numbers, independent from the measurement units of the criteria. The higher the weight, the more important the criterion. Let the set $\left\{w_{j}, j=1\right.$, ..., $k\}$ represents the weights of relative importance of the different criteria. Then:

$$
\sum_{j=1}^{k} w_{j}=1 .
$$

Several techniques can be used to determine the weights of the criteria. In this study, the AHP method is preferred.

3. Determine the preference function, which translates the difference between the evaluations obtained by two alternatives into a preference degree ranging from zero to one, for each criterion. Six types of preference functions were proposed: 1) usual; 2) U-shape; 3) V-shape; 4) level; 5) linear; and 6) Gaussian. The preference structure of PROMETHEE is based on pairwise comparisons, which means that the deviation between the evaluations of two alternatives on a particular criterion is taken into account:

$$
P_{j}(a, b)=F_{j}\left[d_{j}(a, b)\right] j=1, \ldots, k,
$$

where: $P_{j}(a, b)$ denotes the preference of alternative $a$ with regard to alternative $b$ on each criterion $j$ as a function of the $d_{j}(a, b)$, which is defined as:

$$
\operatorname{dj}(a, b)=g j(a)-g j(b),
$$

where: $g_{j}(a)$ is the evaluation of alternative $a$ on the criterion $j$, and $g_{j}(b)$ is the evaluation of alternative $b$ on the criterion $j$.

4. Determine the threshold values for each criterion, which are; 1) the value of an indifference threshold $(q), 2)$ the value of a strict preference threshold $(p)$, and 3) the Gaussian threshold ( $s$ ). Indifference threshold $q$ is the largest deviation to consider as negligible on that criterion. Preference threshold $p$ is the smallest deviation to consider decisive in the preference of one alternative over another. Gaussian threshold $s$ is only used with Gaussian preference function and it is an intermediate value between $p$ and $q$.

5. Calculate aggregated preference indices:

$$
\pi(a, b)=\sum_{j=1}^{k} P_{j}(a, b) w_{j},
$$

where: $\pi(a, b)$ is expressing with which degree $a$ is preferred to $b$ over all the criteria.

6. Calculate outranking flows (The PROMETHEE I partial ranking). Each alternative $a$ is facing other alternatives in $A$. Two outranking flows are defined:

The positive outranking flow:

$$
\phi^{+}(a)=\frac{1}{n-1} \sum_{x \in A} \pi(a, x) .
$$

The negative outranking flow:

$$
\phi^{-}(a)=\frac{1}{n-1} \sum_{x \in A} \pi(x, a),
$$

where: $\phi^{+}(a)$ is the positive outranking flow that denotes the measure of outranking character of alternative $a$ (how $a$ dominates all other alternatives of $A$ ), $\phi^{-}(a)$ is the negative outranking flow that denotes the measure of outranked character of alternative $a$ (how $a$ is dominated by all other alternatives of $A$ ), and $n$ is the number of alternatives.

$\mathrm{aPb}$ if: $\phi^{+}(a)>\phi^{+}(b)$ and $\phi^{-}(a)<\phi^{-}(b)$; 
or

$\phi^{+}(a)>\phi^{+}(b)$ and $\phi^{-}(a)=\phi^{-}(b)$;

or

$\phi^{+}(a)=\phi^{+}(b)$ and $\phi^{-}(a)<\phi^{-}(b)$;

aIb if: $\phi^{+}(a)=\phi^{+}(b)$ and $\phi^{-}(a)<\phi^{-}(b)$;

aRb if: $\phi^{+}(a)=\phi^{+}(b)$ and $\phi^{-}(a)>\phi^{-}(b)$;

or

$$
\phi^{+}(a)<\phi^{+}(b) \text { and } \phi^{-}(a)<\phi^{-}(b),
$$

where P, I and R, respectively stand for preference, indifference and incomparability

7. Calculate net outranking flow (The PROMETHEE II complete ranking):

$$
\phi(a)=\phi^{+}(a)-\phi^{-}(a),
$$

where: $\phi(a)$ is the net outranking flow for alternative $a$. The alternative with the higher net flow is considered to be superior.

8. Generate a geometrical analysis for interactive aid (GAIA) plane. This plane displays the relative position of the alternatives graphically, in terms of contributions to the criteria. Principal Component Analysis (PCA) is applied to the matrix of normed flows:

$$
\phi_{j}(a)=\frac{1}{n-1} \sum_{b \neq a}\left[P_{j}(a, b)-P_{j}(b, a)\right] \text {. }
$$

\subsection{Proposed AHP-PROMETHEE integrated approach}

In this study, an integrated approach, which consists of AHP and PROMETHEE methods, is proposed for selecting the most appropriate subcontractor. The proposed approach is composed of four main stages, which include:

1. Data gathering. In this stage, the decision making team, whose members are responsible for evaluating and/or selecting subcontractors, is formed, the criteria that will be used by a construction company in the subcontractor selection process and alternative subcontractors are determined, and the decision hierarchy is developed. It should be noted that these criteria may greatly vary from company to company for several reasons such as the company's strategic plan, size, capacity, specialty level, human resources, equipment, ongoing projects, etc. Therefore, every construction company should determine their own criteria. In the last step of this stage, the decision making team approves the decision hierarchy.

2. AHP computations. In this phase, pairwise comparison matrices are formed to determine the weights of the criteria used in the subcontractor evaluation process, the decision making team members make individual evaluations to determine the values of the elements of the pairwise comparison matrices, the weights of the criteria are calculated using the geometric mean of the values obtained from individual evaluations, a final pairwise comparison matrix is formed, and the decision making team approves the calculated weights of the criteria.
3. PROMETHEE computations. In this stage, the decision making team determines and approves preference functions and parameters, and the subcontractor priorities are found by using PROMETHEE calculations. Partial ranking with PROMETHEE I, complete ranking with PROMETHEE II, and GAIA plane are determined.

4. Decision making. In this phase, the most appropriate subcontractor is selected based on the rankings and GAIA plane provided by PROMETHEE I and II.

\section{A numerical application of the proposed approach}

A case study is presented in order to illustrate how the proposed approach can be applied in a real situation. In the present case, a general contractor, which predominantly undertakes international projects and is mainly specialized in airport construction, intends to subcontract the asphalt work of a car park with the area of $35,500 \mathrm{~m}^{2}$ to a qualified subcontractor. Abdul-Malak and Hassanein (2001) investigated quality- and time-related construction disputes that have arisen in a major asphalt works subcontract awarded on a large airport construction program. They stated that subcontracting this type of operation to a competent subcontractor is vital for preventing potential disputes and improving overall project performance.

\subsection{Data gathering}

First, the decision making team was formed. This team consisted of three civil engineers, who were the employees of the contractor, had at least 20 years of experience in the construction industry, were the members of the project management team in the studied project, and were in charge of the subcontractor selection process. This decision making team selected six subcontractors (i.e. SC-1, SC-2, SC-3, SC-4, SC-5, SC-6) for further evaluation and determined eleven criteria, namely bid price $(\mathrm{C} 1)$, financial status $(\mathrm{C} 2)$, number of key personnel (C3), number of pavers (C4), number of road rollers (C5), number of trucks (C6), number of completed projects with similar size $(\mathrm{C} 7)$, number of ongoing projects (C8), quality of workmanship in past projects (C9), number of fatal incidents in the last three projects $(\mathrm{C} 10)$, and experience of the company in the construction industry (C11), which would be taken into account during the subcontractor selection process. The criteria identified by the decision-makers are consistent with the subcontractor selection criteria proposed by various researchers and summarized in Table 1. The experts stated that these criteria were peculiar to the studied project's conditions and could change from project to project due to the complexity and uniqueness of the project in question. The level of bid price is one of the most important factors that affect the profit margin of a general contractor. Therefore, a subcontractor, who offers the lowest bid price, is more likely to be selected. If a subcontractor has strong financial status, he can offer flexibility in progress payment terms and conditions. Moreover, he unlikely faces 
difficulties in reimbursement to the suppliers or in paying the salary of his staff each month. The subcontractor, who has adequate resources in terms of workers, equipment and materials, can complete the project on time. If a subcontractor has successfully completed many projects with similar size, this means that he has enough capacity and capability for fulfilling the contract requirements. General contractors commonly tend to work with subcontractors, who have fewer work commitments. If a subcontractor has numerous ongoing projects, he has to allocate his resources to these projects. In such a case, he may face scarcity of resources and the problem of coordination, which in turn may bring about delays. The high quality of workmanship and the low number of fatal incidents in past projects indicate that the subcontractor's quality and safety performances are good. If a subcontractor has been doing business in the construction industry for many years, this means that this company can be considered as experienced and competent.

There are three main levels in the structured decision hierarchy. The first level is the overall goal of the decision process, which is defined as "selection of the most appropriate subcontractor". In the second level, there are criteria. The alternative subcontractors are on the third level of the decision hierarchy. Financial status (C2) and quality of workmanship in past projects (C9) were evaluated on a 9-point qualitative scale, which is presented in Table 2, based on past experiences with these subcontractors. The numerical values were used for the calculations.

Table 2. Qualitative scale

\begin{tabular}{ccc}
\hline Qualitative value & Abbreviation & Numerical value \\
\hline Very Bad & VB & 1 \\
\hline Very Bad-Bad & VB-B & 2 \\
\hline Bad & B & 3 \\
\hline Bad-Average & B-A & 4 \\
\hline Average & A & 5 \\
\hline Average-Good & A-G & 6 \\
\hline Good & G & 7 \\
\hline Good-Very Good & G-VG & 8 \\
\hline Very Good & VG & 9
\end{tabular}

\subsection{AHP computations}

Having formed the decision hierarchy for subcontractor selection problem, the relative priorities of the criteria to be used in the selection process were found by using the AHP method. Super Decisions software was utilized to implement the AHP method. In this phase, three experienced civil engineers in the decision making team individually formed their pairwise comparison matrix and geometric means of these values were calculated in order to obtain the final pairwise comparison matrix. The final pairwise comparison matrix on which there is a consensus and the weights of the criteria obtained from AHP computations are presented in Table 3.

Based on the experts' judgments, the bid price (C1), financial status (C2), and number of key personnel (C3) were found to be the most important criteria in the subcontractor selection process. Consistency ratio (CR) of the pairwise comparison matrix is calculated as $0.001<$ 0.10 , which indicates that the judgment matrix is consistent and the weights can be used in the selection process.

\subsection{PROMETHEE computations}

After obtaining the relative priorities of the criteria to be used in the selection process using the AHP method, the evaluation matrix was formed by the decision making team. The evaluation matrix is displayed in Table 4.

In general, a subcontractor, who maximizes profit through low bid price, strong financial status, adequate resources, expertise in similar works, low ongoing work commitments, high quality work, and high safety performance backed with experience in the construction industry, is considered as the best option (Marzouk et al. 2013). However, in real world, it is almost impossible. While a subcontractor may be superior on some of the selection criteria to his competitors, he may be average or inferior on the remaining criteria. As seen in Table 4, while $\mathrm{SC}-1$ is superior on bid price (C1), number of road rollers (C5), and number of completed projects with similar size (C7), he is average or inferior on the remaining criteria. SC-6 is inferior on financial status $(\mathrm{C} 2)$, number of road rollers (C5), number of trucks (C6), and number of completed projects with similar size (C7), whereas he

Table 3. Pairwise comparison matrix for criteria and results obtained from AHP computations

\begin{tabular}{ccccccccccccc}
\hline Criteria & C1 & C2 & C3 & C4 & C5 & C6 & C7 & C8 & C9 & C10 & C11 & Weights \\
\hline C1 & 1.00 & 1.26 & 1.44 & 1.82 & 2.29 & 2.15 & 3.30 & 2.88 & 1.65 & 1.59 & 3.17 & 0.16 \\
\hline C2 & 0.79 & 1.00 & 1.14 & 1.38 & 1.65 & 1.59 & 2.62 & 2.52 & 1.44 & 1.26 & 2.71 & 0.13 \\
\hline C3 & 0.70 & 0.87 & 1.00 & 1.31 & 1.36 & 1.55 & 2.15 & 1.82 & 1.26 & 1.10 & 2.29 & 0.11 \\
\hline C4 & 0.55 & 0.72 & 0.76 & 1.00 & 1.18 & 1.14 & 1.74 & 1.59 & 1.05 & 0.94 & 1.82 & 0.09 \\
\hline C5 & 0.44 & 0.61 & 0.74 & 0.85 & 1.00 & 1.10 & 1.58 & 1.31 & 0.87 & 0.79 & 1.71 & 0.08 \\
\hline C6 & 0.46 & 0.63 & 0.64 & 0.87 & 0.91 & 1.00 & 1.65 & 1.26 & 0.85 & 0.69 & 1.70 & 0.08 \\
\hline C7 & 0.30 & 0.38 & 0.46 & 0.57 & 0.63 & 0.61 & 1.00 & 0.94 & 0.72 & 0.55 & 0.91 & 0.05 \\
\hline C8 & 0.35 & 0.40 & 0.55 & 0.63 & 0.76 & 0.79 & 1.07 & 1.00 & 0.63 & 0.60 & 1.31 & 0.06 \\
\hline C9 & 0.61 & 0.69 & 0.79 & 0.95 & 1.15 & 1.17 & 1.39 & 1.59 & 1.00 & 0.87 & 1.96 & 0.09 \\
\hline C10 & 0.63 & 0.79 & 0.91 & 1.07 & 1.26 & 1.45 & 1.82 & 1.66 & 1.15 & 1.00 & 2.52 & 0.10 \\
\hline C11 & 0.31 & 0.37 & 0.44 & 0.55 & 0.58 & 0.59 & 1.10 & 0.76 & 0.51 & 0.40 & 1.00 & 0.05 \\
\hline
\end{tabular}


Table 4. Evaluation matrix

\begin{tabular}{cccccccccccccc}
\hline Criteria & C1 & C2 & C3 & C4 & C5 & C6 & C7 & C8 & C9 & C10 & C11 \\
\hline Unit & C & - & - & - & - & - & - & - & - & - & Year \\
\hline Min/Max & Min & Max & Max & Max & Max & Max & Max & Min & Max & Min & Max \\
\hline Weight & 0.16 & 0.13 & 0.11 & 0.09 & 0.08 & 0.08 & 0.05 & 0.06 & 0.09 & 0.10 & 0.05 \\
\hline SC-1 & 830,000 & A & 3 & 1 & 8 & 7 & 8 & 3 & A & 3 & 8 \\
\hline SC-2 & $1,075,000$ & A-G & 5 & 2 & 7 & 10 & 5 & 1 & G-VG & 1 & 6 \\
\hline SC-3 & $1,084,000$ & A-G & 3 & 3 & 5 & 8 & 6 & 4 & A & 5 & 10 \\
\hline SC-4 & 980,000 & G & 4 & 2 & 4 & 11 & 2 & 3 & G & 0 & 4 \\
\hline SC-5 & $1,206,000$ & G-VG & 4 & 2 & 6 & 9 & 4 & 0 & A-G & 2 & 5 \\
\hline SC-6 & $1,006,000$ & A-G & 6 & 4 & 5 & 6 & 3 & 2 & G & 1 & 9 \\
\hline
\end{tabular}

is superior or average on the remaining criteria. Since none of the alternative subcontractors is superior on all of the criteria, the ultimate goal of the general contractor is to select the most compromising subcontractor.

In order to rank the alternative subcontractors, the decision making team determined specific preference functions and threshold values for each criterion considering the nature of the criteria, features of the alternative subcontractors, and strategy of the company. The preference functions and threshold values are presented in Table 5.

After inputting the values in the evaluation matrix, preference functions and thresholds, alternative subcontractors were evaluated via Decision Lab software. The positive flow $\left(\phi^{+}\right)$, negative flow $\left(\phi^{-}\right)$, and net flow $(\phi)$ values are provided in Table 6 .

Table 5. Preference functions

\begin{tabular}{ccccc}
\hline \multirow{2}{*}{ Criteria } & Preference & \multicolumn{3}{c}{ Threshold Values } \\
\cline { 3 - 5 } & Function & $q$ & $p$ & $s$ \\
\hline C1 & Linear & 10,000 & 50,000 & - \\
\hline C2 & Level & 0.5 & 1.5 & - \\
\hline C3 & Linear & 1 & 2 & - \\
\hline C4 & Linear & 1 & 2 & - \\
\hline C5 & Linear & 1 & 3 & - \\
\hline C6 & Linear & 1 & 4 & - \\
\hline C7 & Linear & 2 & 4 & - \\
\hline C8 & Linear & 1 & 3 & - \\
\hline C9 & Level & 0.5 & 1.5 & - \\
\hline C10 & Linear & 1 & 3 & - \\
\hline C11 & Linear & 2 & 5 & - \\
\hline
\end{tabular}

Table 6. PROMETHEE flows

\begin{tabular}{crrr}
\hline Alternatives & $\phi^{+}$ & $\phi^{-}$ & $\phi$ \\
\hline SC-1 & 0.2710 & 0.3240 & -0.0530 \\
\hline SC-2 & 0.2840 & 0.1680 & 0.1160 \\
\hline SC-3 & 0.1100 & 0.4020 & -0.2920 \\
\hline SC-4 & 0.3168 & 0.2037 & 0.1131 \\
\hline SC-5 & 0.2210 & 0.2893 & -0.0683 \\
\hline SC-6 & 0.3700 & 0.1858 & 0.1842 \\
\hline
\end{tabular}

The partial ranking was determined using the positive and negative flow values via PROMETHEE I (see Fig. 1).

According to the PROMETHEE I partial ranking, SC-3 is the worst alternative and SC-6, SC-4, SC-2, SC-1 and $\mathrm{SC}-5$ are preferred to $\mathrm{SC}-3$ alternative. SC-2 alternative is preferred to $\mathrm{SC}-1$ and $\mathrm{SC}-5$ alternatives. Also, $\mathrm{SC}-6$ is preferred to $\mathrm{SC}-4$ alternative. On the other hand, SC-6 and SC-2, SC-4 and SC-2, and SC-1 and SC-5 are incomparable alternatives. It is obvious that the PROMETHEE I partial ranking did not provide information about the most compromising alternative. In order to identify the most compromising alternative, the complete ranking was determined using the net flow values given via PROMETHEE II (see Fig. 2).

SC-6 alternative was selected as the most compromising alternative based on the information provided by the PROMETHEE II complete ranking. The other alternatives are ranked in the order of SC-2, SC-4, SC-1, SC-5 and SC-3.

One of the most important features of Decision Lab software is that it provides users with the GAIA plane, which is the result of Principal Component Analysis (PCA). In this plane, alternatives are represented by points and criteria by vectors. The GAIA plane for subcontractor selection is presented in Figure 3.

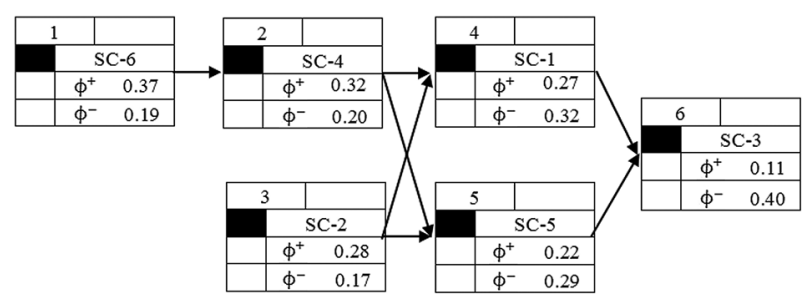

Fig. 1. PROMETHEE I partial ranking

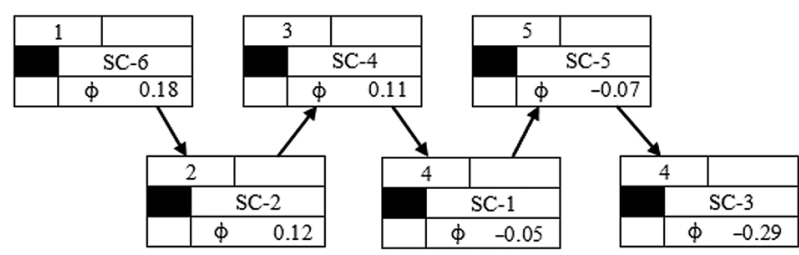

Fig. 2. PROMETHEE II complete ranking 


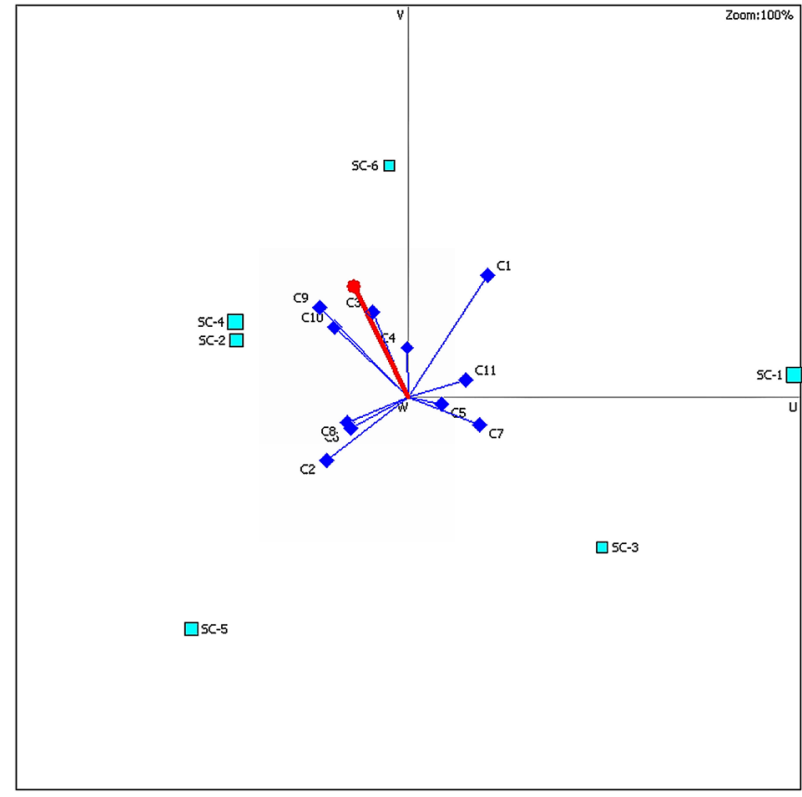

Fig. 3. GAIA plane for subcontractor selection

The length of each vector is a measure of its strength in alternative subcontractors' differentiation. As seen in Figure 3, Bid Price (C1) has the highest differentiation strength and expresses independent preferences. In the GAIA plane, consistent criteria are positioned in the same direction whereas conflicting criteria are oriented in opposite directions. It can be observed that Number of Road Rollers (C5) and Number of Completed Projects with Similar Size (C7) are consistent criteria and express similar preferences. On the other hand, Bid Price (C1) and Financial Status (C2), Number of Trucks (C6), and Number of Ongoing Projects (C8) are conflicting criteria and express opposite preferences. The position of an alternative determines the strength or weakness of this alternative with respect to different criteria. For instance, SC-5 is particularly good on Financial Status (C2) and Number of Ongoing Projects (C8), whereas SC-6 is predominantly good on Number of Key Personnel (C3), Number of Pavers (C4), Quality of Workmanship in Past Projects (C9), Number of Fatal Accidents in the Last Three Projects (C10), and Experience of the Company in the Construction Industry (C11).

Vector $p i$, which is the decision axis, represents the direction of compromise deriving from the weighted criteria. The decision makers should appreciate the alternatives located in that direction. As it can be seen from Figure 3, vector $p i$ is oriented in the direction of Number of Key Personnel (C3) and Number of Pavers (C4), and the closest alternative to the vector $p i$ is SC-6, which indicates that it is the most compromising option. Contrary to it, the alternative SC-3 is the worst option because it is oriented in the opposite direction of vector pi. This finding is also consistent with the PROMETHEE II complete ranking result.

\subsection{Decision making}

Based on the AHP and PROMETHEE computations, it is decided that SC-6 is the most appropriate subcontractor for the asphalt work of a car park. In order to analyze how the variation in the criteria weights will affect the ranking, sensitivity analysis was performed via Decision Lab software. The stability intervals values are given in Table 7.

Table 7. Stability intervals

\begin{tabular}{cccc}
\hline \multirow{2}{*}{ Criteria } & Weight & \multicolumn{2}{c}{ Intervals } \\
\cline { 3 - 4 } & $\left(w_{j}\right)$ & Min & Max \\
\hline C1 & 0.16 & 0.0721 & 0.3772 \\
\hline C2 & 0.13 & 0.0000 & 0.2221 \\
\hline C3 & 0.11 & 0.0419 & 1.0000 \\
\hline C4 & 0.09 & 0.0234 & 1.0000 \\
\hline C5 & 0.08 & 0.0000 & 0.1617 \\
\hline C6 & 0.08 & 0.0000 & 0.1314 \\
\hline C7 & 0.05 & 0.0000 & 0.2260 \\
\hline C8 & 0.06 & 0.0000 & 0.1969 \\
\hline C9 & 0.09 & 0.0000 & 0.2226 \\
\hline C10 & 0.10 & 0.0000 & 0.3360 \\
\hline C11 & 0.05 & 0.0000 & 0.7922 \\
\hline
\end{tabular}

The stability intervals specify each criterion's weight limits within which the result of PROMETHEE II complete ranking does not change. It can be seen from Table 7 that the weights of the criteria are not very sensitive and any minuscule changes in the weights of the criteria will not change the complete ranking. For instance, if the weight of Bid Price (C1) criterion is set to be lower than 0.0721 or higher than 0.3772 , the complete ranking will substantially change. When the weights of the criteria were set as $0.38(\mathrm{C} 1), 0.09(\mathrm{C} 2), 0.08(\mathrm{C} 3), 0.07$ (C4), 0.06 (C5), 0.06 (C6), 0.04 (C7), 0.04 (C8), 0.07 (C9), 0.07 (C10), and 0.04 (C11) considering the stability intervals and the relative weights of the criteria, the complete ranking would be as; SC-1, SC-6, SC-4, SC-2, $\mathrm{SC}-3$, and SC-5. The decision-making team stated that as the lowest bid price was offered by SC-1, it was very reasonable that $\mathrm{SC}-1$ ranked first when the weight of the bid price criterion $(\mathrm{C} 1)$ was increased.

After performing the sensitivity analysis, the case in which all criteria have equal weights was analyzed. The net flow values obtained for this situation and their comparisons with previous values are given in Table 8 .

While SC-6 and SC-2 ranked first and second according to the weighted ranking results, their rankings interchanged when the criteria weights were considered to be equal. SC-1 and SC-5 ranked fourth and fifth in the original case, on the other hand, their rankings also switched when the criteria weights were removed. SC-4 ranked third and SC-3 was the worst alternative in both cases. 
Table 8. Weighted and unweighted rankings

\begin{tabular}{ccccc}
\hline Alter. & $\begin{array}{c}\text { Weighted } \\
\phi\end{array}$ & $\begin{array}{c}\text { Weighted } \\
\text { Ranking }\end{array}$ & $\begin{array}{c}\text { Unweighted } \\
\phi\end{array}$ & $\begin{array}{c}\text { Unweighted } \\
\text { Ranking }\end{array}$ \\
\hline SC-6 & $\mathbf{0 . 1 8 4 2}$ & $\mathbf{1}$ & $\mathbf{0 . 1 4 7 3}$ & $\mathbf{2}$ \\
\hline SC-2 & $\mathbf{0 . 1 1 6 0}$ & $\mathbf{2}$ & $\mathbf{0 . 1 5 4 5}$ & $\mathbf{1}$ \\
\hline SC-4 & 0.1131 & 3 & 0.0133 & 3 \\
\hline SC-1 & $\mathbf{- 0 . 0 5 3 0}$ & $\mathbf{4}$ & $\mathbf{- 0 . 0 5 4 5}$ & $\mathbf{5}$ \\
\hline SC-5 & $\mathbf{- 0 . 0 6 8 3}$ & $\mathbf{5}$ & $\mathbf{- 0 . 0 3 3 3}$ & $\mathbf{4}$ \\
\hline SC-3 & -0.2920 & 6 & -0.2273 & 6 \\
\hline
\end{tabular}

\section{Conclusions}

Main contractors generally subcontract large portions or all of the specialized work on their projects to subcontractors. Since the actual production work is predominantly carried out by subcontractors, choosing the right subcontractor for the right job has a critical impact on overall project performance. Traditionally, main contractors tend to select the subcontractors based on the lowest bid price. However, this type of selection may result in inefficiencies and project failures. Therefore, main contractors should consider a combination of various compromising and conflicting criteria in order to select the most appropriate subcontractor.

An integrated decision approach, which employs AHP and PROMETHEE together, proposed in this paper can improve the subcontractor evaluation process and help main contractors for the selection of the most appropriate subcontractor among a set of available alternatives. The selection problem is based on the comparisons of different subcontractor alternatives according to the identified criteria. In this approach, AHP is used to formulate the structure of the subcontractor selection problem and to determine the weights of the criteria, and the PROMETHEE method is employed to determine the priorities of the alternatives based on the criteria weights obtained from AHP and preference functions determined by the decision makers.

Subcontractor selection problem could have been approached using only AHP or PROMETHEE. These two techniques have their own strengths and weaknesses. One of the strengths of AHP is that it decomposes a decision problem into its smallest elements and builds a decision hierarchy (i.e., goal, main criteria, sub-criteria, alternatives, etc.). Thereby, it enables decision makers to see the importance of each criterion, obtain a clear view of the decision problem, and evaluate the results. However, PROMETHEE does not provide this structuring possibility. In the AHP method, the weights of the elements are obtained through a sequence of pairwise comparisons. On the other hand, it is not clear how these weights should be determined in PROMETHEE. Two of the most important weaknesses of AHP are the need for a substantial number of pairwise comparisons and the artificial limitation of the use of 9-point scale. In contrast, PROMETHEE needs only the evaluations of the alternatives on different criteria and enables users to evaluate the alternatives using numerical data. In this study, these techniques are used together in order to mix the strengths of both techniques and thereby achieve operational synergies (Macharis et al. 2004).

The proposed approach has been applied to a problem of selecting the most appropriate subcontractor in a construction company, which is mainly specialized in airport construction. In the studied case, although SC-1 offered the lowest bid price ( $€ 830,000)$, SC-6 was found to be the most appropriate alternative based on the proposed approach. The bid price offered by SC-6 was $€ 176,000$ more than the bid price offered by SC-1. When these two alternative subcontractors were compared, it was observed that while SC-1 is superior on bid price (C1), number of road rollers (C5), and number of completed projects with similar size (C7), SC-6 was superior on number of key personnel (C3), number of pavers (C4), quality of workmanship in past projects (C9), number of fatal accidents in the last three projects (C10), and experience of the company in the construction industry (C11). The decision-making team stated that this type of operation required the extensive use of equipment and high quality of workmanship. Thus, the subcontractor, who employed more qualified personnel, had more pavers, better quality and safety performance, and more experience in the construction industry, was more likely to be selected. According to the decision-making team, although selecting SC-6 instead of SC-1 would bring an extra cost of $€ 176,000$, the potential benefits (i.e., on-time completion, fewer reworks, better occupational safety, improved client satisfaction, and better reputation) that would be gained by working with SC-6 would compensate for this additional cost. Indeed, in this project, the construction company worked with SC-6 and did not experience any serious problems in terms of time, quality, and safety. Company management found the proposed approach satisfactory and implementable in future subcontractor selection problems. It should be noted that the proposed approach can be successfully used by construction companies' management teams if they have knowledge of AHP and PROMETHEE techniques and are capable of determining the preference functions and the threshold values for each criterion correctly.

The proposed integrated decision approach is of benefit to construction companies. The benefits can be summarized as follows:

- Elimination of the dependence on the lowest bid price;

- Consideration of a combination of various compromising and conflicting criteria;

- More systematic evaluation;

- Visual representation of the subcontractor selection problem;

- Sensitivity analysis;

- Faster selection process;

- Lower cost of the selection process;

- User friendly system;

- More objectivity. 
In some cases, a number of criteria may have an uncertain structure and cannot be measured precisely. In such circumstances, fuzzy numbers can be used to develop the evaluation matrix. This may improve the proposed integrated decision approach and is one of the future directions in this research. Moreover, specific value functions can be used for considering non-linearity in the assessment of each selection criterion (see, for instance, Alarcón et al. 2011).

\section{References}

Abbasianjahromi, H.; Rajaie, H.; Shakeri, E. 2013. A framework for subcontractor selection in the construction industry, Journal of Civil Engineering and Management 19(2): $158-168$. http://dx.doi.org/10.3846/13923730.2012.743922

Abdul-Malak, M. U.; Hassanein, Z. 2001. Asphalt works subcontracting disputes in large construction programs, Journal of Performance of Constructed Facilities 15(2): 62-67.

http://dx.doi.org/10.1061/(ASCE)0887-3828(2001)15:2(62)

Alarcón, B.; Aguado, A.; Manga, R.; Josa, A. 2011. A value function for assessing sustainability: application to industrial buildings, Sustainability 3(1): 35-50. http://dx.doi.org/10.3390/su3010035

Alarcón, L. F.; Mourgues, C. 2002. Performance modelling for contractor selection, Journal of Management in Engineering 18(2): 52-60.

http://dx.doi.org/10.1061/(ASCE)0742-597X(2002)18:2(52)

Albino, V.; Garavelli, A. C. 1998. A neural network application to subcontractor rating in construction firms, International Journal of Project Management 16(1): 9-14. http://dx.doi.org/10.1016/S0263-7863(97)00007-0

Arditi, D.; Chotibhongs, R. 2005. Issues in subcontracting practice, Journal of Construction Engineering and Management 131(8): 866-876.

http://dx.doi.org/10.1061/(ASCE)0733-9364(2005)131:8(866)

Arslan, G. 2012. Web-based contractor evaluation system for mass-housing projects in Turkey, Journal of Civil Engineering and Management 18(3): 323-334. http://dx.doi.org/10.3846/13923730.2012.698892

Arslan, G.; Kivrak, S.; Birgonul, M. T.; Dikmen, I. 2008. Improving sub-contractor selection process in construction projects: web-based subcontractor evaluation system (WEBSES), Automation in Construction 17(4): 480-488. http://dx.doi.org/10.1016/j.autcon.2007.08.004

Behzadian, M.; Kazemzadeh, R. B.; Albadvi, A.; Aghdasi, M. 2010. PROMETHEE: A comprehensive literature review on methodologies and applications, European Journal of Operational Research 200(1): 198-215. http://dx.doi.org/10.1016/j.ejor.2009.01.021

Bendaña, R.; del Caño, A.; de la Cruz, M. P. 2008. Contractor selection: fuzzy-control approach, Canadian Journal of Civil Engineering 35(5): 473-486. http://dx.doi.org/10.1139/L07-127

Bendaña-Jácome, R.; Del Caño-Gochi, A.; De la CruzLópez, P.; Castro-Rascado, A. 2010. Selección multicriterio de contratistas de obras. Enfoque basado en redes neuronales, Dyna Ingeniería e Industria 85(1): 71-84.

Bogdanovic, D.; Nikolic, D.; Ilic, I. 2012. Mining method selection by integrated AHP and PROMETHEE method, Anais da Academia Brasileria de Ciências 84(1): 219-233. http://dx.doi.org/10.1590/S0001-37652012005000013

Brans, J.; Mareschal, B. 2005. PROMETHEE methods, in J. Figueira, G. Salvatore, M. Ehrgott (Eds). Multiple criteria decision analysis: State of the art surveys. New York: Springer, 163-196.
Brauers, W. K. M.; Zavadskas, E. K.; Turskis, Z.; Vilutiene, T. 2008. Multi-objective contractor's ranking by applying the MOORA method, Journal of Business Economics and Management 9(4): 245-255. http://dx.doi.org/10.3846/1611-1699.2008.9.245-255

Cheng, E. W. L.; Li, H. 2004. Contractor selection using the analytic network process, Construction Management and Economics 22(10): 1021-1032. http://dx.doi.org/10.1080/0144619042000202852

Choudhry, R. M.; Hinze, J. W.; Arshad, M.; Gabriel, H. F. 2012. Subcontracting practices in the construction industry of Pakistan, Journal of Construction Engineering and Management 138(12): 1353-1359.

http://dx.doi.org/10.1061/(ASCE)CO.1943-7862.0000562

Cooke, B.; Williams, P. 1998. Construction planning, programming and control. UK, Basingstoke: Macmillan Press Ltd. $504 \mathrm{p}$.

Cox, R. F.; Issa, R. R. A.; Frey, A. 2006. Proposed subcontractor-based employee motivational model, Journal of Construction Engineering and Management 132(2): 152-163.

http://dx.doi.org/10.1061/(ASCE)0733-9364(2006)132:2(152)

Dagdeviren, M. 2008. Decision making in equipment selection: an integrated approach with AHP and PROMETHEE, Journal of Intelligent Manufacturing 19(4): 397-406. http://dx.doi.org/10.1007/s10845-008-0091-7

Darvish, M.; Yasaei, M.; Saeedi, A. 2009. Application of the graph theory and matrix methods to contractor ranking, International Journal of Project Management 27(6): 610 619. http://dx.doi.org/10.1016/j.ijproman.2008.10.004

Elazouni, A. M.; Metwally, F. G. 2000. D-SUB: Decision support system for subcontracting construction works, Journal of Construction Engineering and Management 126(3): 191-200.

http://dx.doi.org/10.1061/(ASCE)0733-9364(2000)126:3(191)

Eom, C. S. J.; Yun, S. H.; Paek, J. H. 2008. Subcontractor evaluation and management framework for strategic partnering, Journal of Construction Engineering and Management 134(11): 842-851.

http://dx.doi.org/10.1061/(ASCE)0733-9364(2008)134:11(842)

Fong, P. S.-W.; Choi, S. K.-Y. 2000. Final contractor selection using the analytical hierarchy process, Construction Management and Economics 18(5): 547-557. http://dx.doi.org/10.1080/014461900407356

Hartmann, A.; Caerteling, J. 2010. Subcontractor procurement in construction: the interplay of price and trust, Supply Chain Management: An International Journal 15(5): 354-362.

Hartmann, A.; Ling, F. Y. Y.; Tan, J. S. H. 2009. Relative importance of subcontractor selection criteria: evidence from Singapore, Journal of Construction Engineering and Management 135(9): 826-832.

http://dx.doi.org/10.1061/(ASCE)0733-9364(2009)135:9(826)

Hatush, Z.; Skitmore, M. 1998. Contractor selection using multicriteria utility theory: an additive model, Building and Environment 33(2-3): 105-115. http://dx.doi.org/10.1016/S0360-1323(97)00016-4

Hinze, J.; Tracey, A. 1994. The contractor-subcontractor relationship: the subcontractors' views, Journal of Construction Engineering and Management 120(2): 274-287.

http://dx.doi.org/10.1061/(ASCE)0733-9364(1994)120:2(274)

Holt, G. D.; Olomolaiye, P. O.; Harris, F. C. 1994. Applying multiattribute analysis to contractor selection decisions, European Journal of Purchasing \& Supply Management 1(3): 139148. http://dx.doi.org/10.1016/0969-7012(94)90003-5

Hsieh, T. Y. 1998. Impact of subcontracting on site productivity: Lessons learned in Taiwan, Journal of Construction Engineering and Management 124(2): 91-100.

http://dx.doi.org/10.1061/(ASCE)0733-9364(1998)124:2(91) 
Humphreys, P.; Matthews, J.; Kumaraswamy, M. 2003. Preconstruction project partnering: from adversarial to collaborative relationships, Supply Chain Management: An International Journal 8(2): 166-178.

Ip, W. H.; Yung, K. L.; Wang, D. 2004. A branch and bound algorithm for sub-contractor selection in agile manufacturing environment, International Journal of Production Economics 87(2): 195-205.

http://dx.doi.org/10.1016/S0925-5273(03)00125-7

Juan, Y.-K.; Perng, Y.-H.; Castro-Lacouture, D.; Lu, K.-S. 2009. Housing refurbishment contractors selection based on a hybrid fuzzy-QFD approach, Automation in Construction 18(2): 139-144.

http://dx.doi.org/10.1016/j.autcon.2008.06.001

Karim, K.; Marosszeky, M; Davis, S. 2006. Managing subcontractor supply chain for quality in construction, Engineering, Construction and Architectural Management 13(1): 27-42. http://dx.doi.org/10.1108/09699980610646485

Ko, C.-H.; Cheng, M.-Y.; Wu, T.-K. 2007. Evaluating subcontractors performance using EFNIM, Automation in Construction 16(4): 525-530.

http://dx.doi.org/10.1016/j.autcon.2006.09.005

Kumaraswamy, M. M.; Matthews, J. D. 2000. Improved subcontractor selection employing partnering principles, Journal of Management in Engineering 16(3): 47-57.

http://dx.doi.org/10.1061/(ASCE)0742-597X(2000)16:3(47)

Luu, D. T.; Sher, W. 2006. Construction tender subcontract selection using case-based reasoning, Australian Journal of Construction Economics and Building 6(2): 31-43.

Macharis, C.; Brans, J. P.; Mareschal, B. 1998. The GDSS PROMETHEE Procedure, Journal of Decision Systems 7: 283307. http://dx.doi.org/10.1016/S0377-2217(03)00153-X

Macharis, C.; Springael, J.; De Brucker, K.; Verbeke, A. 2004. PROMETHEE and AHP: the design of operational synergies in multicriteria analysis. Strengthening PROMETHEE with ideas of AHP, European Journal of Operational Research 153(2): 307-317.

Mahdi, I. M.; Riley, M. J.; Fereig, S. M.; Alex, A. P. 2002. A multi-criteria approach to contractor selection, Engineering, Construction and Architectural Management 9(1): 2937. http://dx.doi.org/10.1046/j.1365-232X.2002.00228.x

Marzouk, M. M.; El Kherbawy, A. A.; Khalifa, M. 2013. Factors influencing sub-contractors selection in construction projects, HBRC Journal 9(2): 150-158. http://dx.doi.org/10.1016/j.hbrcj.2013.05.001

Mbachu, J. 2008. Conceptual framework for the assessment of subcontractors' eligibility and performance in the construction industry, Construction Management and Economics 26(5): 471-484. http://dx.doi.org/10.1080/01446190801918730

Ng, S. T.; Tang, Z.; Palaneeswaran, E. 2009. Factors contributing to the success of equipment-intensive subcontractors in construction, International Journal of Project Management 27(7): 736-744. http://dx.doi.org/10.1016/j.ijproman.2008.09.006

Ngowi, A. B.; Pienaar, E. 2005. Trust factor in construction alliances, Building Research and Information 33(3): 267278. http://dx.doi.org/10.1080/09613210500042895

Okoroh, M. I.; Torrance, V. B. 1999. A model for subcontractor selection in refurbishment projects, Construction Management and Economics 17(3): 315-327. http://dx.doi.org/10.1080/014461999371529

Palaneeswaran, E.; Kumaraswamy, M. M. 2000. Contractor selection for design/build projects, Journal of Construction Engineering and Management 126(5): 331-339.

http://dx.doi.org/10.1061/(ASCE)0733-9364(2000)126:5(331)

Saaty, T. L. 1980. The analytic hierarchy process. New York: McGraw-Hill. 287 p.
Shash, A. A. 1998. Bidding practices of subcontractors in Colorado, Journal of Construction Engineering and Management 124(3): 219-225.

http://dx.doi.org/10.1061/(ASCE)0733-9364(1998)124:3(219)

Singh, D.; Tiong, R. L. K. 2005. A fuzzy decision framework for contractor selection, Journal of Construction Engineering and Management 131(1): 62-70.

http://dx.doi.org/10.1061/(ASCE)0733-9364(2005)131:1(62)

Singh, D.; Tiong, R. L.K. 2006. Contractor selection criteria: investigation of opinions of Singapore construction practitioners, Journal of Construction Engineering and Management 132(9): 998-1008.

http://dx.doi.org/10.1061/(ASCE)0733-9364(2006)132:9(998)

Sönmez, M.; Holt, G. D.; Yang, J. B.; Graham, G. 2002. Applying evidential reasoning to prequalifying construction contractors, Journal of Management in Engineering 18(3): 111-119.

http://dx.doi.org/10.1061/(ASCE)0742-597X(2002)18:3(111)

Topcu, Y. I. 2004. A decision model proposal for construction contractor selection in Turkey, Building and Environment 39(4): 469-481. http://dx.doi.org/10.1016/j.buildenv.2003.09.009

Tserng, H. P.; Lin, P. H. 2002. An accelerated subcontracting and procuring model for construction projects, Automation in Construction 11(1): 105-125. http://dx.doi.org/10.1016/S0926-5805(01)00056-5

Turcksin, L.; Bernardini, A.; Macharis, C. 2011. A combined AHP-PROMETHEE approach for selecting the most appropriate policy scenario to stimulate a clean vehicle fleet, Procedia - Social and Behavioral Science 20: 954-965.

Ulubeyli, S.; Manisali, E.; Kazaz, A. 2010. Subcontractor selection practices in international construction projects, Journal of Civil Engineering and Management 16(1): 47-56. http://dx.doi.org/10.3846/jcem.2010.04

Venkatesan, S. P.; Kumanan, S. 2012. Supply chain risk prioritisation using a hybrid AHP and PROMETHEE approach, International Journal of Services and Operations Management 13(1): 19-41. http://dx.doi.org/10.1504/IJSOM.2012.048274

Waara, F.; Bröchner, J. 2006. Price and nonprice criteria for contractor selection, Journal of Construction Engineering and Management 132(8): 797-804.

http://dx.doi.org/10.1061/(ASCE)0733-9364(2006)132:8(797)

Wang, J. J.; Yang, D. L. 2007. Using a hybrid multi-criteria decision aid method for information systems outsourcing, Computers \& Operations Research 34(12): 3691-3700. http://dx.doi.org/10.1016/j.cor.2006.01.017

Wong, C. H.; Holt, G. D.; Cooper, P.A. 2000. Lowest price or value? Investigation of UK construction clients' tender selection process, Construction Management and Economics 18(7): 767-774. http://dx.doi.org/10.1080/014461900433050

Zavadskas, E. K.; Vilutienė, T. 2006. A multiple criteria evaluation of multi-family apartment block's maintenance contractors: I-Model for maintenance contractor evaluation and the determination of its selection criteria, Building and Environment 41(5): 621-632. http://dx.doi.org/10.1016/j.buildenv.2005.02.019

Zavadskas, E. K.; Turskis, Z.; Vilutiene, G, T. 2005. Simulation of multi-criteria selection of buildings' maintenance contractor using the game theory, Computer Modelling and New Technologies 9(2): 7-16.

Zavadskas, E. K.; Turskis, Z.; Tamošaitienè, J. 2008. Contractor selection of construction in a competitive environment, Journal of Business Economics and Management 9(3): 181187. http://dx.doi.org/10.3846/1611-1699.2008.9.181-187

Zavadskas, E. K.; Kaklauskas, A.; Turskis, Z.; Tamošaitienė, J. 2009a. Multi-attribute decision-making model by applying grey numbers, Informatica 20(2): 305-320. 
Zavadskas, E. K.; Kaklauskas, A.; Vilutiene, T. 2009b. Multicriteria evaluation of apartment blocks maintenance contractors: Lithuanian case study, International Journal of Strategic Property Management 13(4): 319-338. http://dx.doi.org/10.3846/1648-715X.2009.13.319-338
Zavadskas, E. K.; Vilutienė, T.; Turskis, Z.; Tamošaitienė, J. 2010. Contractor selection for construction works by applying SAW-G and TOPSIS grey techniques, Journal of Business Economics and Management 11(1): 34-55. http://dx.doi.org/10.3846/jbem.2010.03

Gul POLAT. She is an Associate Professor of Civil Engineering at Istanbul Technical University, where she also serves as the Director of the Construction Management Graduate Program. She conducted her PhD studies at Istanbul Technical University and Illinois Institute of Technology in Chicago. Her main areas of research interest include decision support techniques, resource management, marketing management, risk management, precast concrete systems, and most aspects of construction management. She has been involved with several research projects funded by The Scientific and Technological Research Council of Turkey (TUBITAK), Istanbul Technical University (ITU), Feyzi Akkaya Fund for Supporting Scientific Activities (FABED), and other construction industry agencies. Her research work over the years has resulted in 74 technical papers in refereed journals and proceedings. She has served over the years on several organizing committees of national and international conferences. Dr. Polat is currently serving on the editorial board of an international journal and routinely reviews papers for several scholarly publications. 